\title{
WSPÓŁCZESNE MIEJSKIE SYSTEMY TRANSPORTOWE W KONTEKŚCIE ZRÓWNOWAŻONEGO ROZWOJU W POLSCE
}

\author{
Katarzyna Sosik ${ }^{1}$ \\ Akademia Morska w Szczecinie \\ Wydział Inżynieryjno-Ekonomiczny Transportu
}

\begin{abstract}
Streszczenie: Zapewnienie efektywnego i sprawnego przemieszczania się ładunków i osób w miejskich systemach transportowych wpływa na jakość życia i wzrost konkurencyjności wobec innych miast. Koncepcja zrównoważonego rozwoju miast stanowi odpowiedź na ich dynamiczny wzrost, zmieniające się potrzeby ich mieszkańców oraz na konieczność ograniczania negatywnych skutków funkcjonowania miejskich systemów transportowych. Celem artykułu jest identyfikacja działań planowanych przez zarządców wybranych polskich miast w kontekście rozwoju zrównoważonych systemów transportu. $\mathrm{W}$ ramach realizowanych badań zostały przeanalizowane strategie rozwoju pod względem opracowanych celów i zamierzonych działań. W publikacji wykorzystano metody analizy źródeł, analizę opisową oraz metodę dedukcji. Do weryfikacji poszczególnych aspektów artykułu posłużyła analiza literatury polsko- i anglojęzycznej.
\end{abstract}

Słowa kluczowe: miejski system transportu, strategia rozwoju miasta, zrównoważony rozwój, zrównoważony system transportu

DOI: $10.17512 /$ znpcz.2020.3.05

\section{Wprowadzenie}

Organizacja Narodów Zjednoczonych oszacowała, że do 2020 roku w miastach będzie mieszkać $80 \%$ populacji. Dynamicznie rozwijające się miasta na całym świecie oraz związany z tym wzrost liczby ich mieszkańców wpływa na wzmożone zapotrzebowanie na usługi transportowe. $\mathrm{W}$ związku $\mathrm{z}$ dużym natężeniem ruchu w miastach obserwuje się jego negatywny wpływ na sferę społeczną, ekonomiczną oraz na środowisko.

Coraz więcej organizacji, instytucji, środowisk badawczo-naukowych, specjalistów promuje realizację zadań $\mathrm{w}$ mieście zgodnych z założeniami zrównoważonego rozwoju. Determinantą zmian w mieście jest czynnik intelektualny, czyli społeczeństwa dążące do podnoszenia swoich kwalifikacji i umiejętności (Bonenberg 2012, s. 91). Obecnie staje się istotne implikowanie rozwiązań $\mathrm{w}$ zakresie systemów transportu w mieście na miarę najbardziej rozwijających się miast na świecie.

\footnotetext{
${ }^{1}$ Katarzyna Sosik, mgr inż., k.sosik@am.szczecin.pl, ORCID: 0000-0003-1298-9955
} 
Sprawny i efektywny system transportu warunkuje atrakcyjność i konkurencyjność kraju, regionu, miasta. Przez wzgląd na występowanie dużej gęstości zaludnienia oraz charakter zagospodarowania przestrzennego w mieście zauważa się, że organizacja transportu na obszarach zurbanizowanych stanowi ważne i jednocześnie trudne zadanie (Korneć 2018).

System transportowy miasta jest dostosowany do jego specyfiki. Kluczowe zatem staje się zidentyfikowanie problemów systemu transportowego w danym mieście oraz opracowanie koncepcji jego rozwoju. Pomimo unikatowego charakteru każdego z miast, w ich strategiach doszukać się można zasadniczych podobieństw w kontekście rozwoju systemu transportowego.

$\mathrm{W}$ odniesieniu do wdrażania zmian w mieście istotna staje się współpraca pomiędzy wieloma środowiskami. W miastach europejskich programy rozwoju są opracowywane przede wszystkim na gruncie celów opublikowanych przez Organizację Narodów Zjednoczonych oraz celów Komisji Europejskiej. W Polsce plany rozwoju miast są opracowywane przez ich władze, przy uwzględnieniu konsultacji innych środowisk. Programy te są udostępniane do informacji publicznej jako strategie na ustalony czas.

Celem artykułu jest identyfikacja planów działania wybranych trzech miast w Polsce w kontekście rozwoju miejskich systemów transportowych. Dane Głównego Urzędu Statystycznego umożliwiły dobór próby badawczej, tj. wybranie trzech najbardziej zaludnionych miast wojewódzkich. W artykule wykorzystano metody analizy źródeł, analizę opisową oraz metodę dedukcji.

\section{Miasta na drodze do zrównoważonego rozwoju}

Pierwsze miasta powstawały wraz z podziałem pracy na zajęcia rolnicze i pozarolnicze, przyczyniając się do zapoczątkowania wymiany oraz zaspokajania potrzeb egzystencjonalnych i społecznych. Łączenie się mniejszych jednostek osadniczych w większe miało na celu rozwój handlu oraz zwiększenie możliwości obronnych. Zasadniczą determinantą wpływającą na lokalizację zakładania miast był dostęp do wody ze względu na możliwość wykorzystania ekonomicznych szlaków transportowych. Miasta średniowieczne wykonywały określone podstawowe funkcje umożliwiające spełnianie podstawowych potrzeb mieszkańców oraz pobliskich wsi, na które mogły wywierać wpływ (Szołtysek 2005, s. 12-17; Szymańska 2007, s. 24).

Okres industrialny nazywany rewolucją przemysłową przyniósł zmiany w wielu obszarach życia społeczeństwa. Wynalezienie maszyny parowej oraz związana z tym zwiększona sprawność fabryk produkcyjnych przyczyniła się do powstania bezrobocia oraz zmniejszenia zapotrzebowania na rolną siłę roboczą ze względu na zapoczątkowanie masowej produkcji. Zmiany w strukturach zatrudnienia spowodowały masowy napływ mieszkańców obszarów wiejskich do miast, w których było zapotrzebowanie na siłę roboczą. Szybka migracja ludzi pogłębiła procesy urbanizacyjne na świecie pod koniec XIX wieku (Szołtysek 2005, s. 20-21).

Wzmożona masowa migracja społeczeństwa do miast obserwowana była na całym świecie, ale ten proces nie przebiegał we wszystkich krajach jednocześnie. Koncentracja ludzi w miastach przyczyniła się do rozwoju przemysłu, handlu i usług. 
Umiejscowienie węzłów transportowych stanowiło ważny aspekt życia społecznego ze względu na możliwe szybkie przemieszczanie się siły roboczej. Fabryki przemysłowe rozwijały się, co w konsekwencji przyczyniało się do powstania nowych miejsc pracy oferowanych osobom spoza miast (Szołtysek 2005, s. 25). W następstwie ludność osiedlała się bliżej nowych miejsc pracy.

W pierwszej połowie XX wieku zauważono, że model miasta ściśle związany jest ze szklakami komunikacyjnymi. Dostępność transportowa decydowała o lokalizowaniu nowych inwestycji i zwiększaniu atrakcyjności danego obszaru. Po II wojnie światowej kierunek rozwoju zabudowy uległ zmianie. W literaturze proces ten nazywany jest suburbanizacją. W okresie tym zauważa się wzrost liczby inwestycji w zabudowę, szczególnie mieszkalną na przedmieściach miast zamieszkałych przez osoby zamożne (Szołtysek 2005, s. 29; Szymańska 2007, s. 47).

Rozwój miast stał się wynikiem podnoszenia standardów życia społeczeństwa. Czynniki warunkujące rozwój miast na przestrzeni lat ewoluowały. Niezmiennym warunkiem przyczyniającym się do postępu w miastach jest położenie względem otoczenia z dostępem między innymi do szlaków morskich, rzecznych, do kopalń czy do terenów rolniczych lub w okolicy atrakcyjnych środowisk naturalnych. W literaturze można znaleźć wiele podziałów tych czynników skategoryzowanych w sposób indywidualny. Jednakże powtarzającymi się czynnikami są: czynnik społeczny warunkowany przez przedsiębiorczość mieszkańców, czynniki lokalizacji obiektów przemysłowych, transportu, obiektów mieszkalnych, czynniki infrastrukturalne ujęte w szerokim znaczeniu społeczno-technicznym. Inną grupą czynników warunkującą rozwój miast są potrzeby, do których zaliczyć można potrzeby mieszkańców, które w przestrzeni czasu zmieniają się wraz ze wzrostem poziomu życia, oczekując od odpowiednich podmiotów podjęcia działań w danym zakresie, potrzeby rozszerzania działalności przez jednostki gospodarcze przede wszystkim przez wdrażanie innowacyjnych rozwiązań techniczno-technologicznych, potrzeby aktywności społecznej i edukacyjnej (Stawasz 2016, s. 77-82).

Współczesne miasta cechują: tymczasowość, zróżnicowanie przestrzenne, odmienne style życia, różnorodność kultur oraz kontrast między bogatymi i biednymi. Globalizacja i związana z nią rewolucja technologiczna przyczyniły się do zmiany podejścia $\mathrm{w}$ zarządzaniu miastem. Takie podejście wymuszało spojrzenie na miasto z perspektywy wielopoziomowości, włączając $\mathrm{w}$ zarządzanie miastem różne grupy interesariuszy. Zarządzanie wielopoziomowe miastem charakteryzuje się między innymi: współpracą podmiotów kierujących się różnymi logikami w podejmowaniu decyzji, horyzontalnymi formami interakcji, wysokim stopniem racjonalności refleksyjnej i innymi (Wiktorska-Święcka 2016, s. 25-27). Współczesne zarządzanie miastem, w tym systemem transportowym, oznacza skuteczne planowanie, organizowanie, przywództwo oraz kontrolowanie wszystkich procesów.

Wzrost zamożności społeczeństwa, chęć podnoszenia jakości życia, transformacja potrzeb społecznych, uprzemysłowienie i urbanizacja przyczyniły się do pozytywnych zjawisk zachodzących w miastach, ale równocześnie wywierają negatywny wpływ na środowisko. Pierwsza definicja zrównoważonego rozwoju została przedstawiona w 1987 roku w Raporcie Brundtland, gdzie została ujęta jako zaspokajanie potrzeb społeczeństwa, przy zapewnieniu zaspokojenia przynajmniej na tym samym 
poziomie potrzeb następnym pokoleniom. W bliższym znaczeniu zrównoważony rozwój określa się jako efektywne i racjonalne zarządzanie ograniczonymi zasobami oraz poszukiwanie alternatywnych możliwości dla obecnego i kolejnych pokoleń Rzeńca (red.) 2016, s. 50-51).

Rozwój zrównoważony określany jest jako wieloetapowy i długofalowy proces międzypokoleniowy, konsekwentnie przynoszący zmiany, zarówno ilościowe, jak i jakościowe. W istocie zrównoważonego rozwoju uczestniczy kapitał przyrodniczy, społeczny i ekonomiczny, współpracując i oddziaływując wzajemnie na siebie (Stawasz 2016, s. 88). Upowszechnienie koncepcji zrównoważonego rozwoju miało miejsce na początku lat 90. XX wieku, a przyczyniła się do tego konferencja „Środowisko i Rozwój” w Brazylii oraz inicjatywa ONZ. Wzmocnienie znaczenia koncepcji zrównoważonego rozwoju w wymiarze praktycznych działań wiązało się $\mathrm{z}$ opublikowaniem programów w tym zakresie. Jednym z działań było upowszechnienie Agendy 21, która odnosiła się do wartości władz lokalnych we wdrażaniu koncepcji zrównoważonego rozwoju. Związane jest to z zarządzaniem przez władze systemem ekologiczno-społeczno-gospodarczym w miastach, gminach, które to mają realny wpływ na osiągnięcie celów w wymiarze krajowym, a następnie globalnym (Rzeńca (red.) 2016, s. 51-53; Chłąd, Strzelczyk, Chłąd 2018, s. 218-219). W osiągnięciu założonych przez miasta celów istotne staje się spojrzenie na nie w sposób holistyczny (Mirabella, Allacker 2018, s. 83).

Dynamiczny proces wdrażania koncepcji zrównoważonego rozwoju w miastach obserwuje się od końca XX wieku. Władze miast poszukują swoich ścieżek rozwoju, które odpowiadałyby bieżącym oczekiwaniom. Indywidualna droga wdrażania koncepcji rozwoju pozwala zarządcom miast na kształtowanie przewagi konkurencyjnej (Rzeńca (red.) 2016, s. 53; Nowakowska-Grunt, Chłąd 2015, s. 129). Stąd też wynikają niejednorodne plany programowe i strategiczne opracowane przez poszczególne miasta, przede wszystkim opierające się na zasadach opublikowanych przez Komisję Europejską bądź ONZ.

\section{Współczesne miejskie systemy transportowe}

Pierwsze stałe osady umożliwiały zaspokajanie potrzeb ich społeczności. Wraz z podziałem pracy na zajęcia rolnicze i pozarolnicze istotnym czynnikiem rozwoju stały się szlaki komunikacyjne. Pierwsze miasta zlokalizowane były przy ekonomicznych ciągach transportowych, np. przy ujściu rzek (Szołtysek 2005, s. 16-17). Obecnie na całym świecie transport pełni kluczową rolę w strukturze miasta, a przede wszystkim wpływa na rozwój gospodarczy.

Wzrost procesów urbanizacyjnych rzutuje na ewolucję wymagań użytkowników miast. Obserwuje się zmiany potrzeb odnoszących się do miejskiego transportu w zakresie zwiększenia ich liczby oraz podnoszenia jakości proponowanych usług. Dotyczy to zarówno przewozów pasażerskich, jak i towarowych. Stawiane przed zarządcami miast wymagania stanowią dla nich wyzwanie w zakresie finansowania, planowania i realizacji działań oraz ich ciągłego nadzoru (Iwan 2013, s. 12; Kijewska 2014, s. 2929). 
Miejski system transportowy stanowi integralną część obszaru zurbanizowanego miasta, jest jednym z czynników wpływających na jego rozwój oraz na jakość życia jego mieszkańców. Jego podstawowy cel to przemieszczanie osób oraz dystrybucja towarów na obszarach miejskich (Chamier-Gliszyński 2012; Krysiuk, Nowacki 2016). Według literatury miejski system transportowy zdefiniować można za pomocą modelu, na który składają się cztery czynniki (Chamier-Gliszyński 2012):

$$
M S T=\{G, F, P, O\}
$$

Gdzie:

$M S T$ - miejski systemy transportowy,

$G$ - graf struktury miejskiego systemu transportowego,

$F$ - zbiór funkcji określonych na węzłach i łukach grafu,

$P$ - potok ruchu,

$O$ - organizacja miejskiego systemu transportowego.

Rosnące zapotrzebowanie na przewozy do obszarów zurbanizowanych lub wewnątrz nich wynikają z rosnącej liczby miast oraz użytkowników. Realizowane przewozy stanowią niezbędny element w utrzymaniu funkcji społecznej i ekonomicznej miast, a także wzmagają pojawiające się problemy wynikające z negatywnego oddziaływania systemu transportowego na społeczeństwo i środowisko naturalne. Przede wszystkim przyczyniają się do powstawania kongestii transportowej, inaczej zwanej zatorami drogowymi. Efekt kongestii w następstwie powoduje wzrost zanieczyszczenia środowiska, hałas, większe prawdopodobieństwo wystąpienia wypadków drogowych (Iwan 2013, s. 10-14; Sosik, Iwan 2018, s. 249-251).

Istotnym elementem $\mathrm{w}$ efektywnym zarządzaniu systemem transportowym w mieście jest infrastruktura transportowa. Pomimo ciągłej rozbudowy i modernizacji elementów infrastruktury, przy rosnącej liczbie uczestników ruchu drogowego jest ona niewystarczająca. Dodatkowo rozbudowa infrastruktury wiąże się z koniecznością ingerencji w środowisko, to znaczy pod jej budowę przeznacza się duży obszar, który z kolei ulega degradacji w wyniku działalności transportu (Klepacki, Koper 2017, s. 8). Według statystyk liczba pojazdów zarejestrowanych w Polsce od lat 90. XX wieku stale rośnie. W Tabeli 1 została przedstawiona liczba pojazdów silnikowych zarejestrowanych w Polsce od 2016 do 2019 roku (KGP 2019). W przedstawionych danych statystycznych tendencja liczby pojazdów zarejestrowanych w Polsce rosła w latach 2016-2019, a w analizowanych skrajnych latach był to wzrost o prawie $10 \%$. Kategoria pojazdów silnikowych uwzględnia pojazdy osobowe, ciężarowe oraz motocykle.

Tabela 1. Liczba pojazdów silnikowych zarejestrowanych w Polsce w latach 2016-2019

\begin{tabular}{|c|c|c|}
\hline Rok & Pojazdy silnikowe & $\mathbf{2 0 1 6}-\mathbf{1 0 0 \%}$ \\
\hline 2016 & 28601037 & $100 \%$ \\
\hline 2017 & 29634928 & $103,61 \%$ \\
\hline 2018 & 30800790 & $107,69 \%$ \\
\hline 2019 & 31388643 & $109,75 \%$ \\
\hline
\end{tabular}

Źródło: Opracowanie własne na podstawie danych statystycznych Komendy Głównej Policji 
Uczestnicy miejskich systemów transportowych są istotnym ogniwem systemów transportowych, jak również przyczyniają się do negatywnych skutków przez nie wywieranych, między innymi na środowisko. Jednym z istotniejszych czynników są wypadki drogowe, które według statystyk publikowanych w raportach przez Główną Komendę Policji najliczniej występują na terenach zabudowanych. Przyczyny wypadków można podzielić pod względem grup uczestników je inicjujących. W ostatnich latach zwraca się szczególną uwagę na błędy ludzkie wynikające z braku predyspozycji, braku aktualnych szkoleń, nietrzeźwości i innych. Pozostałymi przyczynami wypadków drogowych są: infrastruktura drogowa (np. niewłaściwy stan jezdni, brak lub niedostateczne oświetlenie) oraz stan techniczny środków transportu (np. usterki układu hamulcowego, braki w ogumieniu).

Znaczenia nabiera rozwój miejskich systemów transportowych w dobie społeczeństwa informacyjnego, inaczej nazywanego również społeczeństwem wiedzy. Kapitał ludzki stanowi jedną z głównych ról w rozwoju poszczególnych regionów. Powszechny dostęp do zasobów Internetu wzmacnia ten proces. W odpowiedzi na szerszą możliwość wysyłania danych oraz komunikacji władze miast coraz częściej wykorzystują nowoczesne technologie telematyczne. Implementacja rozwiązań telematycznych efektywnie wpływa na realizowane przepływy w obszarze miast (Malecki, Iwan, Kijewska 2014, s. 215).

Problematyka systemów transportowych w miastach skupia uwagę polityki transportowej Unii Europejskiej. Szczególnie biorąc pod uwagę założenie, że do 2020 roku miało mieszkać w miastach UE $80 \%$ jej obywateli. Priorytety opracowane przez Komisję Europejską na lata 2019-2024 dotyczą wdrażania rozwiązań na rzecz zrównoważonego rozwoju (https://ec.europa.eu/...). Koncepcja budowania zielonej infrastruktury, promowania niskoemisyjnych lub zeroemisyjnych pojazdów drogowych, zwiększanie sieci ładowania pojazdów elektrycznych, zastąpienie w większym stopniu transportu drogowego alternatywnymi gałęziami transportu, zmniejszanie hałasu w miastach, wzrost bezpieczeństwa jego mieszkańców - to jedne z zadań na najbliższy okres dla miast Unii Europejskiej.

Państwa członkowskie Unii Europejskiej odniosły się do zadań opracowanych przez Komisję Europejską, tworząc na ich podstawie swoje cele strategiczne na kolejne lata. W następstwie miasta europejskie w odpowiedzi na wymagania unijne, potrzeby społeczne oraz dążenie do wzrostu atrakcyjności i konkurencyjności prowadzą lokalne działania.

\section{Metodyka badań}

W artykule wykorzystano metody analizy źródeł, analizy opisowej oraz metodę dedukcji. Autorka artykułu koncentruje się na pytaniu, w jaki sposób władze miast dążą do prowadzenia zrównoważonego systemu transportu $\mathrm{w}$ miastach. Aby odpowiedzieć na to pytanie, zostały wybrane według statystyk Głównego Urzędu Statystycznego trzy najbardziej zaludnione miasta wojewódzkie, tj.: Warszawa, Łódź i Kraków (GUS 2018). Analiza opiera się na opublikowanych strategiach lokalnych i obejmuje podejmowane działania przez zarządców miast. 
Do badania wybrano miasta wojewódzkie, ze względu na pełnioną funkcję w regionie. Układy metropolitalne uważane są za główny motor rozwoju całego regionu. Wykorzystanie potencjału stolic wojewódzkich pozwala na zwiększenie konkurencyjności samego miasta, jak i na wzrost atrakcyjności całego regionu (Dziemianowicz, Slachta, Szmigiel-Rakowska 2011, s. 9).

Podczas analizy dokumentów strategicznych wybranych miast dotyczących planowanego rozwoju miejskich systemów transportowych wystąpiła duża rozpiętość informacji. Ze względu na dostęp do obszernego materiału konieczne było dokonanie hasłowych sformułowań czy też interpretacji ogólnikowej.

\section{Planowane dzialania wybranych miast w Polsce w kontekście rozwoju systemów transportowych zgodnie z koncepcją zrównoważonego rozwoju}

\section{Program miasta Warszawy}

Dokument przedstawiony przez władze miasta Warszawy dotyczy planów strategicznych i został opublikowany w 2018 roku. Nosi on nazwę: Strategia \#Warszawa 2030. Została w nim przedstawiona wizja Warszawy na 2030 rok, cele strategiczne wynikające $\mathrm{z}$ wizji oraz cele operacyjne stanowiące plan osiągnięcia poszczególnych celów strategicznych (Strategia \#Warszawa 2030, 2018). Cele szczegółowe są opracowane w taki sposób, aby miały wzajemny wpływ na siebie, tworząc efekt synergii. W Tabeli 2 zostały przedstawione cele szczegółowe oraz odnoszące się do nich cele operacyjne.

Tabela 2. Strategia rozwoju Warszawy

\begin{tabular}{|c|c|c|c|c|}
\hline Lp. & $\begin{array}{c}\text { Cele } \\
\text { strategiczne }\end{array}$ & Lp. & $\begin{array}{c}\text { Cele } \\
\text { operacyjne }\end{array}$ & $\begin{array}{c}\text { Wskaźnik sukcesu } \\
\text { z realizowanego celu }\end{array}$ \\
\hline \multirow{2}{*}{1.} & \multirow{2}{*}{$\begin{array}{l}\text { Odpowiedzialna } \\
\text { wspólnota }\end{array}$} & 1.1 & $\begin{array}{c}\text { Dbamy o siebie } \\
\text { nawzajem }\end{array}$ & $\begin{array}{c}\text { Odsetek mieszkańców } \\
\text { angażujących się społecznie }\end{array}$ \\
\hline & & 1.2 & $\begin{array}{l}\text { Wspólnie decydujemy } \\
\text { o naszym mieście }\end{array}$ & $\begin{array}{l}\text { Odsetek mieszkańców angażu- } \\
\text { jących się w sprawy miasta }\end{array}$ \\
\hline \multirow{4}{*}{2.} & \multirow{4}{*}{$\begin{array}{l}\text { Wygodna } \\
\text { lokalność }\end{array}$} & 2.1 & $\begin{array}{l}\text { Mamy dostęp do } \\
\text { szerokiej oferty } \\
\text { mieszkań }\end{array}$ & $\begin{array}{c}\text { Odsetek mieszkańców } \\
\text { pozytywnie oceniających } \\
\text { możliwość kupna i wynajęcia } \\
\text { mieszkania za rozsądną cenę }\end{array}$ \\
\hline & & 2.2 & $\begin{array}{l}\text { Aktywnie spędzamy czas } \\
\text { wolny blisko domu }\end{array}$ & $\begin{array}{c}\text { Odsetek mieszkańców } \\
\text { korzystających z oferty wol- } \\
\text { nego czasu i rozwoju w swojej } \\
\text { dzielnicy zamieszkania }\end{array}$ \\
\hline & & 2.3 & $\begin{array}{l}\text { Korzystamy z usług } \\
\text { blisko domu }\end{array}$ & $\begin{array}{c}\text { Indeks korzystających } \\
\text { z podstawowych usług w po- } \\
\text { bliżu miejsca zamieszkania }\end{array}$ \\
\hline & & 2.4 & $\begin{array}{c}\text { Działamy w warunkach } \\
\text { przyjaznych } \\
\text { dla rozwoju biznesu }\end{array}$ & $\begin{array}{l}\text { Odsetek firm pozytywnie oce- } \\
\text { niających warunki rozwoju } \\
\text { działalności gospodarczej }\end{array}$ \\
\hline
\end{tabular}




\begin{tabular}{|c|c|c|c|c|}
\hline Lp. & $\begin{array}{c}\text { Cele } \\
\text { strategiczne }\end{array}$ & Lp. & $\begin{array}{c}\text { Cele } \\
\text { operacyjne }\end{array}$ & $\begin{array}{l}\text { Wskaźnik sukcesu } \\
\text { z realizowanego celu }\end{array}$ \\
\hline \multirow{3}{*}{3.} & \multirow{3}{*}{$\begin{array}{l}\text { Funkcjonalna } \\
\text { przestrzeń }\end{array}$} & 3.1 & $\begin{array}{c}\text { Korzystamy } \\
\text { z atrakcyjnej przestrzeni } \\
\text { publicznej }\end{array}$ & $\begin{array}{c}\text { Ocena mieszkańców zadowolo- } \\
\text { nych z jakości przestrzeni } \\
\text { publicznej w centrum miasta }\end{array}$ \\
\hline & & 3.2 & $\begin{array}{c}\text { Żyjemy w czystym } \\
\text { środowisku przyrodniczym }\end{array}$ & $\begin{array}{c}\text { Indeks jakości środowiska } \\
\text { przyrodniczego }\end{array}$ \\
\hline & & 3.3 & $\begin{array}{c}\text { Korzystamy z przyjaznego } \\
\text { systemu } \\
\text { transportowego }\end{array}$ & $\begin{array}{l}\text { Indeks zadowolenia z jakości } \\
\text { przemieszczania po mieście }\end{array}$ \\
\hline \multirow{4}{*}{4.} & \multirow{4}{*}{$\begin{array}{l}\text { Twórcze } \\
\text { środowisko }\end{array}$} & 4.1 & $\begin{array}{l}\text { Rozwijamy nasz } \\
\text { twórczy potencjał }\end{array}$ & $\begin{array}{l}\text { Odsetek mieszkańców rozwijają- } \\
\text { cych swoje kompetencje }\end{array}$ \\
\hline & & 4.2 & $\begin{array}{l}\text { Generujemy } \\
\text { innowacje }\end{array}$ & $\begin{array}{c}\text { Odsetek przedsiębiorców } \\
\text { z sektorów innowacyjnego } \\
\text { i kreatywnego zadowolonych } \\
\text { z warunków do generowania } \\
\text { i rozwoju innowacji }\end{array}$ \\
\hline & & 4.3 & $\begin{array}{c}\text { Przyciągamy talenty } \\
\text { i liderów } \\
\end{array}$ & $\begin{array}{c}\text { Indeks przyciągania talentów } \\
\text { i liderów }\end{array}$ \\
\hline & & 4.4 & Inspirujemy świat & $\begin{array}{l}\text { Indeks obecności na arenie } \\
\text { międzynarodowej }\end{array}$ \\
\hline
\end{tabular}

W strategii rozwoju Warszawy cele strategiczne nr 1, 3 i 4 odnoszą się do zrównoważonych systemów transportu w mieście. Cele operacyjne dla pierwszego celu strategicznego w omawianym kontekście dotyczą (Strategia \#Warszawa 2030, 2018):

- angażowania mieszkańców w tworzenie mądrej wspólnoty, zwiększanie ich wpływu na zarządzanie Warszawą i podejmowanie decyzji dotyczących funkcjonowania miasta;

- rozwoju współzarządzania, który wiąże się z usprawnieniem przepływu informacji, i wdrażaniu elementów z zakresu zarządzania wiedzą.

Kolejnym celem strategicznym nawiązującym do analizowanej problematyki jest cel $\mathrm{nr} 2$, dotyczący funkcjonalnej przestrzeni, a za realizację tego celu są odpowiedzialne biura zajmujące się polityką przestrzenną, polityką w zakresie ochrony środowiska oraz polityką transportową. Cele operacyjne skupiają się przede wszystkim na:

- połączeniu centrum miasta $\mathrm{z}$ sąsiadującymi dzielnicami oraz $\mathrm{z}$ subdzielnicami w spójną sieć proponującą mieszkańcom i turystom dostęp do szerokiej oferty usług, zielonej infrastruktury, dostępnego i transparentnego systemu informacji, gwarantując tym samym swobodę przemieszczania uwzględniającą likwidację barier architektonicznych;

- zwiększaniu bezpieczeństwa mieszkańców;

- eliminacji czynników wpływających na zdrowie, do których zalicza się hałas, zanieczyszczenie powietrza, gleby i wód;

- efektywnym gospodarowaniu odpadami, upowszechnieniu rozwiązań odnawialnych źródeł energii, promowaniu postaw proekologicznych w społeczeństwie, zwiększeniu obszarów zielonych w mieście, co prowadzi do poprawy ochrony klimatu; 
- zwiększeniu efektywności systemu transportowego w ścisłym centrum, między dzielnicami oraz na obszarze metropolitalnym przez rozbudowę sieci transportowej oraz dostosowanie przystanków do potrzeb mieszkańców i turystów. Zadania skupiają się nie tylko na rozwoju transportu publicznego, ale także mają na celu rozwinięcie systemu transportu rowerowego, jak również stopniowe wprowadzanie ograniczeń poruszania się pojazdów silnikowych w strefach miast charakteryzujących się dużym wskaźnikiem zanieczyszczenia powietrza;

- promowaniu środków transportu o napędzie innym niż tradycyjne w pojazdach indywidualnych i środków transportu publicznego.

Czwarty w kolejności cel strategiczny nazwany został: Twórcze środowisko. W kontekście zrównoważonego miejskiego systemu transportu działania w ramach tego punktu obejmują:

- wzmożoną współpracę między podmiotami świata nauki, biznesu, kultury oraz lokalnych obywateli;

- wspieranie rozwoju wiedzy w społeczeństwie, zdobywania nowych umiejętności, promowanie kreatywnego myślenia społeczeństwa;

- wdrażanie rozwiązań innowacyjnych oraz zapewnienie wsparcia ich twórcom w planowaniu i rozwijaniu oraz prezentowaniu swoich pomysłów.

\section{Program miasta Lodzi}

Program miasta Łodzi został przedstawiony jako Strategia Zintegrowanego Rozwoju Łodzi 2020+. Projekt ten zawiera dhugookresowe wyzwania i problemy miasta i został uchwalony w 2012 roku. Przedstawia on wizję opierającą się na trzech sektorach:

- gospodarka i infrastruktura,

- społeczeństwo i kultura,

- przestrzeń i miasto.

Innym dokumentem strategicznym jest Strategia Rozwoju Łódzkiego Obszaru Metropolitalnego, gdzie zostało wyszczególnionych 5 celów strategicznych wraz z priorytetami przypisanymi do danego celu (Tabela 3).

Tabela 3. Strategia rozwoju obszaru metropolitalnego Lodzi

\begin{tabular}{|c|c|c|c|}
\hline Lp. & Cel & Lp. & Priorytet \\
\hline \multirow{3}{*}{1} & \multirow{3}{*}{$\begin{array}{l}\text { Wzmocnienie funk- } \\
\text { cji metropolitalnych } \\
\text { i spójności obszaru } \\
\text { metropolitalnego }\end{array}$} & 1.1 & $\begin{array}{l}\text { Integracja i koordynacja polityk publicznych na rzecz } \\
\text { podniesienia efektywności realizacji zadań i projektów }\end{array}$ \\
\hline & & 1.2 & $\begin{array}{c}\text { Zwiększenie wewnętrznej i zewnętrznej atrakcyjności ŁOM } \\
\text { poprzez odpowiednio ukierunkowany } \\
\text { marketing terytorialny }\end{array}$ \\
\hline & & 1.3 & $\begin{array}{c}\text { Transfer i komercjalizacja wiedzy na potrzeby } \\
\text { nowoczesnej, konkurencyjnej gospodarki } \\
\text { i społeczeństwa }\end{array}$ \\
\hline \multirow[t]{2}{*}{2.} & \multirow{2}{*}{$\begin{array}{l}\text { Rewitalizacja } \\
\text { obszarów } \\
\text { zdegradowanych } \\
\text { w miastach }\end{array}$} & 2.1 & $\begin{array}{l}\text { Zintegrowane działania rewitalizacyjne w wymiarze prze- } \\
\text { strzennym, przyrodniczym, społecznym, } \\
\text { gospodarczym i kulturowym }\end{array}$ \\
\hline & & 2.2 & $\begin{array}{l}\text { Budowanie i ochrona tożsamości ŁOM oraz kreowanie } \\
\text { wizerunku w oparciu o spójne dziedzictwo kulturowe }\end{array}$ \\
\hline
\end{tabular}


Katarzyna Sosik

\begin{tabular}{|c|c|c|c|}
\hline Lp. & Cel & Lp. & Priorytet \\
\hline \multirow[b]{2}{*}{3.} & \multirow{2}{*}{$\begin{array}{c}\text { Budowa } \\
\text { zintegrowanego } \\
\text { i zrównoważonego } \\
\text { systemu transportu } \\
\text { metropolitalnego }\end{array}$} & 3.1 & $\begin{array}{l}\text { Integracja, modernizacja i rozwój sieci } \\
\text { metropolitalnego transportu zbiorowego }\end{array}$ \\
\hline & & 3.2 & $\begin{array}{l}\text { Modernizacja i rozwój infrastruktury transportu } \\
\text { publicznego }\end{array}$ \\
\hline \multirow{3}{*}{4} & \multirow{3}{*}{$\begin{array}{l}\text { Rozwój gospodarki } \\
\text { zasobooszczędnej } \\
\text { i niskoemisyjnej oraz } \\
\text { ochrona środowiska } \\
\text { przyrodniczego }\end{array}$} & 4.1 & $\begin{array}{c}\text { Podniesienie efektywności energetycznej i wzrost } \\
\text { znaczenia odnawialnych źródeł energii }\end{array}$ \\
\hline & & 4.2 & $\begin{array}{l}\text { Zintegrowanie działań na rzecz rozwoju infrastruktury } \\
\text { komunalnej }\end{array}$ \\
\hline & & 4.3 & $\begin{array}{c}\text { Wspieranie efektywnego wykorzystania zasobów } \\
\text { przyrodniczych, w tym gospodarka odpadami } \\
\text { i ochrona środowiska }\end{array}$ \\
\hline \multirow[b]{2}{*}{5.} & \multirow{2}{*}{$\begin{array}{l}\text { Rozwój nowocze- } \\
\text { snego kapitału } \\
\text { ludzkiego oraz } \\
\text { silnego informacyj- } \\
\text { nego społeczeństwa } \\
\text { obywatelskiego }\end{array}$} & 5.1 & Wspieranie włączenia społecznego \\
\hline & & 5.2 & $\begin{array}{c}\text { Podnoszenie standardów i dostępu do usług w zakresie } \\
\text { oświaty, opieki zdrowotnej i pomocy społecznej } \\
\text { oraz do e-usług publicznych }\end{array}$ \\
\hline
\end{tabular}

Źródło: Opracowanie własne na podstawie dokumentu (Strategia Rozwoju Łódzkiego Obszaru Metropolitalnego 2020+)

Rozwój miejskich systemów transportowych został określony w poniższych priorytetach:

- (1.1) integracja i koordynacja polityk publicznych na rzecz podniesienia efektywności realizacji zadań i projektów - identyfikowanie i rozwiązywanie lokalnych problemów społecznych, kulturowych, gospodarczych, przestrzennych, środowiskowych dzięki współpracy władzy samorządowej, społeczeństwa, przedsiębiorców i innych interesariuszy;

- (1.3) transfer i komercjalizacja wiedzy na potrzeby nowoczesnej, konkurencyjnej gospodarki i społeczeństwa - współpraca ośrodków naukowych, podmiotów publicznych i przedsiębiorstw stanowi kluczowy element w budowaniu przewagi konkurencyjnej przy wykorzystaniu dostępnego potencjału intelektualnego;

- (2.1) zintegrowane działania rewitalizacyjne w wymiarze przestrzennym, przyrodniczym, społecznym, gospodarczym i kulturowym - kompleksowy zakres działań uwzględniający elementy infrastrukturalne, gospodarcze, społeczne, środowiskowe w celu rewitalizacji zdegradowanych obszarów, przywracając im jakość i atrakcyjność dla mieszkańców i turystów; działania techniczne w tym zakresie pozwolą również na promowanie gospodarki niskoemisyjnej;

- (2.3) budowa zintegrowanego i zrównoważonego systemu transportu metropolitalnego - działania w zakresie poprawy funkcjonowania i zintegrowania sieci transportu zbiorowego działającego lokalnie, regionalnie, krajowo oraz międzynarodowo, wspieranie działań służących rozwojowi gospodarki niskoemisyjnej; 
- (3.1) integracja, modernizacja i rozwój sieci metropolitalnego transportu zbiorowego - rozbudowa i modernizacja zarówno infrastruktury transportu, jak i taboru w transporcie publicznym, wprowadzenie biletu aglomeracyjnego, rozwój parkingów park\&ride oraz bike \&ride, co w efekcie ma na celu wzmocnienie pozycji Łodzi w Polsce centralnej przy jednoczesnym działaniu zgodnym z zasadami zrównoważonego rozwoju;

- (3.2) modernizacja i rozwój infrastruktury transportu publicznego - poprawę bezpieczeństwa uczestnikom ruchu drogowego ma przynieść przede wszystkim modernizacja i rozbudowa infrastruktury transportowej miasta;

- (4.1) podniesienie efektywności energetycznej i wzrost znaczenia odnawialnych źródeł energii - współpraca wielu podmiotów, wykorzystywanie innowacyjnych rozwiązań, m.in. w oświetleniu, oraz związana z tym wymiana oświetlenia ulicznego, promowanie gospodarki niskoemisyjnej powinny przyczyniać się do ochrony środowiska i klimatu;

- (4.3) wspieranie efektywnego wykorzystania zasobów przyrodniczych, w tym gospodarka odpadami i ochrona środowiska - inwestowanie w rozwiązania w zakresie gospodarowania odpadami, budowa infrastruktury zielonej;

- (5.1) wspieranie włączenia społecznego - wspieranie przedsiębiorczości, wdrażanie innowacyjnych rozwiązań rozwija społeczeństwo wiedzy, które jest kluczowym elementem rozwoju miast.

\section{Program miasta Krakowa}

Dokument przedstawiony przez władze Krakowa dotyczy rozwoju społeczno-gospodarczego miasta. Nosi on nazwę: Strategia Rozwoju Krakowa. Tu chcę żý. Kraków 2030. Plan ten został opublikowany w 2018 roku, a wyszczególnione są w nim trzy aspiracje (Strategia Rozwoju Krakowa 2018):

- Stać się jednym z dwu najważniejszych miast w Polsce.

- Stać się silną europejską metropolią.

- Być miastem inteligentnym (Smart City).

W dążeniu do osiągnięcia założonych rezultatów zostały wyszczególnione cele strategiczne podzielone na zadania, przedstawione w Tabeli 4.

Tabela 4. Strategia rozwoju Krakowa

\begin{tabular}{|c|c|c|c|}
\hline Lp. & Cele strategiczne & Lp. & Zadania \\
\hline \multirow{2}{*}{1.} & \multirow{2}{*}{$\begin{array}{l}\text { Inteligentna } \\
\text { i nowoczesna } \\
\text { metropolia }\end{array}$} & 1.1 & $\begin{array}{c}\text { Kraków - węzłem w sieci metropolii Polski, } \\
\text { Europy i świata }\end{array}$ \\
\hline & & 1.2 & $\begin{array}{c}\text { Skoordynowane wykorzystywanie potencjałów } \\
\text { Krakowskiego Obszaru Metropolitalnego }\end{array}$ \\
\hline \multirow{3}{*}{2.} & \multirow{3}{*}{$\begin{array}{c}\text { Nowoczesna } \\
\text { gospodarka } \\
\text { i potencjał naukowy }\end{array}$} & 2.1 & Współpraca nauki, biznesu i samorządu \\
\hline & & 2.2 & Wspieranie innowacyjności przedsiębiorstw \\
\hline & & 2.3 & $\begin{array}{l}\text { System kształcenia dostosowany do potrzeb } \\
\text { gospodarki opartej na wiedzy }\end{array}$ \\
\hline \multirow[b]{2}{*}{3.} & \multirow{2}{*}{$\begin{array}{c}\text { Kultura } \\
\text { i dziedzictwo } \\
\text { kulturowe }\end{array}$} & 3.1 & Kraków - miastem europejskiej stolicy kultury \\
\hline & & 3.2 & Wysokie kompetencje kulturalne mieszkańców \\
\hline
\end{tabular}


Katarzyna Sosik

\begin{tabular}{|c|c|c|c|}
\hline Lp. & Cele strategiczne & Lp. & Zadania \\
\hline \multirow{6}{*}{4.} & \multirow{6}{*}{ Jakość życia } & 4.1 & $\begin{array}{l}\text { Powszechnie dostępna, wysokiej jakości } \\
\text { przestrzeń publiczna }\end{array}$ \\
\hline & & 4.2 & Zrewitalizowane obszary miejskie \\
\hline & & 4.3 & Zrównoważone środowisko \\
\hline & & 4.4 & $\begin{array}{l}\text { Przyjazny mieszkańcom, efektywny } \\
\text { i ekologiczny system transportowy }\end{array}$ \\
\hline & & 4.5 & Wysoki poziom bezpieczeństwa w Krakowie \\
\hline & & 4.6 & $\begin{array}{c}\text { Powszechność realizacji idei zdrowego } \\
\text { i aktywnego życia }\end{array}$ \\
\hline \multirow{3}{*}{5.} & \multirow{3}{*}{ Kapitał społeczny } & 5.1 & $\begin{array}{l}\text { Wysoki poziom partycypacji społecznej } \\
\text { mieszkańców }\end{array}$ \\
\hline & & 5.2 & $\begin{array}{c}\text { Silny sektor organizacji społecznych } \\
\text { (pozarządowych) }\end{array}$ \\
\hline & & 5.3 & Spójność społeczna \\
\hline \multirow[b]{2}{*}{6.} & \multirow{2}{*}{$\begin{array}{l}\text { Zarządzanie } \\
\text { miastem }\end{array}$} & 6.1 & Przyjazna i sprawna administracja \\
\hline & & 6.2 & $\begin{array}{c}\text { Wysoka jakość strategicznego zarządzania } \\
\text { miastem }\end{array}$ \\
\hline
\end{tabular}

Źródło: Opracowanie własne na podstawie dokumentu (Strategia Rozwoju Krakowa 2018)

W kontekście zrównoważonego miejskiego systemu transportowego zostały opracowane zamierzenia dotyczące (Strategia Rozwoju Krakowa 2018):

- współpracy gmin w budowaniu atrakcyjnego obszaru metropolitalnego z wykorzystaniem pomysłów środowiska naukowego;

- wsparcia i współpracy różnych środowisk oraz zwiększenia zainteresowania władz miasta nowymi rozwiązaniami techniczno-technologicznymi;

- działań przyczyniających się do budowy systemu szybkiego i bezkolizyjnego szynowego transportu charakteryzującego się parametrami metra;

- rozbudowy sieci dróg rowerowych;

- prac wykonawczych obwodnicy drogowej miasta;

- tworzenia zielonej infrastruktury, kształtowania bezpiecznej przestrzeni dla mieszkańców i turystów;

- ograniczenia ruchu drogowego w centrum miasta, w szczególności ruchu tranzytowego, zintensyfikowania działań związanych z promowaniem usług transportu publicznego i innych ekologicznych form mobilności społeczeństwa, w tym systemu transportu rowerowego;

- wymiany taboru transportu publicznego na niskoemisyjny, ograniczenia emisji hałasu dzięki zastosowaniu cichych torowisk, stawiania ekranów akustycznych, stosowania nawierzchni ograniczającej hałas, ograniczenia dopuszczalnej prędkości dla samochodów silnikowych;

- podejmowania działań w przyznaniu priorytetu dla transportu szynowego w zintegrowanym systemie transportu, rozwijania uprzywilejowania transportu zbiorowego w stosunku do transportu indywidualnego w mieście;

- budowania i modernizacji głównych węzłów przesiadkowych;

- wdrażania rozwiązań współdzielenia indywidualnych środków transportu; 
- podejmowania działań dążących do osiągnięcia wizji zero (czyli brak ofiar śmiertelnych wśród niechronionych uczestników ruchu drogowego);

- podejmowania działań mających na celu komfort i bezpieczeństwo pieszych, m.in. przez likwidację barier architektonicznych, wdrażanie ciągów oświetlenia ulicznego;

- integrowania działań związanych z planowaniem przestrzennym, planowania sieci transportowej miasta;

- wykorzystywania Big Data w budowaniu inteligentnego miasta;

- wprowadzania efektywnego gospodarowania odpadami.

\section{Podsumowanie}

$\mathrm{W}$ artykule zostały poddane analizie plany strategiczne wybranych trzech wojewódzkich polskich miast, Warszawy, Łodzi i Krakowa. Miasta te według Głównego Urzędu Statystycznego charakteryzują się największą liczbą mieszkańców.

Przeprowadzona analiza dla miasta Łodzi opiera się na dokumencie Strategii Rozwoju Łódzkiego Obszaru Metropolitalnego, a nie na Strategii Zintegrowanego Rozwoju Łodzi 2020+ ze względu na dostępność materiału.

Każdy z analizowanych dokumentów zakłada rozwój systemów transportowych, uwzględniając przede wszystkim czynniki infrastrukturalne, środowiskowe, społeczne, techniczno-technologiczne, informatyczne, informacyjne. Zwraca się uwage na wartość intelektualną miasta, współpracę różnych środowisk, rozbudowę i modernizację infrastruktury, rozbudowę zielonej infrastruktury, efektywne gospodarowanie odpadami, wykorzystywanie nowoczesnych technologii, wymianę taboru transportu publicznego oraz promowanie niskoemisyjnych środków transportu, działania na rzecz ograniczania hałasu i wypadków drogowych przyczyniających się do wzrostu bezpieczeństwa.

W miastach Warszawie i Krakowie dąży się do eliminacji ruchu drogowego $\mathrm{z}$ centrum miast. W Krakowie działania opierają się na aspiracji uzyskania efektu wizji zero, czyli zwróceniu uwagi na niechronionych uczestników ruchu drogowego, eliminując śmiertelne wypadki drogowe z udziałem tej grupy uczestników. Warszawa jako jedyna posiada miejski szybki system kolei podziemnej. Kraków w swoich planach założył działania na rzecz budowy szybkiego i bezkolizyjnego systemu transportu szynowego charakteryzującego się parametrami metra. Dodatkowo jako jedyne $\mathrm{z}$ analizowanych miast zamierza wdrażać ciche torowiska oraz ograniczać prędkość w obszarach charakteryzujących się dużym natężeniem ruchu. Kraków prowadzi działania przybliżające go do osiągnięcia statusu inteligentnego miasta, tzn. implementowanie powiązanych i współpracujących rozwiązań w różnych sferach życia, w tym mobilności społeczeństwa, przy wykorzystaniu Big Data.

Podsumowując - planowane rozwiązania z zakresu zrównoważonego systemu transportu w miastach, najobszerniej w swoich programach strategicznych opracował je Kraków, skupiając się na wdrażaniu wielu rozwiązań, przy jednoczesnym wsparciu środowisk uczestniczących w rozwoju miasta. Takie spojrzenie na rozwiązywanie problemów związane jest $\mathrm{z}$ holistycznym spojrzeniem na miasto. 
Badanie obejmujące trzy miasta w Polsce należałoby rozszerzyć w przyszłości o kolejne miasta oraz porównać ich plany strategiczne. Pozwoli to autorce szerzej spojrzeć na badany obszar w kontekście omawianego tematu. Dodatkowo autorka wybrała trzy miasta wojewódzkie, które odzwierciedlają obrane cele innych miast wojewódzkich, ze względu na dążenie do spełnienia wymagań postawionych przez Unię Europejską. Dysproporcje pomiędzy siłą występowania problemów w kontekście funkcjonowania miejskich systemów transportowych są znaczące w miastach wojewódzkich oraz w ośrodkach subregionalnych. Jednakże w rozwoju regionalnym kluczową kwestię stanowi rozwój aglomeracji współdziałającej z mniejszymi ośrodkami. Strategie rozwoju miast w województwach są opracowywane na wzór ich stolic (Dziemianowicz, Slachta, Szmigiel-Rakowska 2011, s. 85-87).

\section{Literatura}

1. Bonenberg A. (2012), Postrzeganie i ocena miejskich przestrzeni publicznych $w$ kontekście rozwoju spoteczeństwa informacyjnego, „Czasopismo Techniczne. Architektura”, z. 1-A/1.

2. Chamier-Gliszczyński N. (2012), Modelowanie miejskiego systemu transportowego, „Logistyka", $\mathrm{nr} 4$.

3. Chłąd M., Strzelczyk M., Chłąd M. (2018), Transport towarów w wybranych miastach w aspekcie założeń zrównoważonego rozwoju, „Prace Naukowe Wyższej Szkoły Zarządzania i Przedsiębiorczości z siedzibą w Wałbrzychu”, $\mathrm{nr}$ 45(1).

4. Dziemianowicz W., Szlachta J., Szmiel-Rawska K. (red.) (2011), Subregionalne bieguny wzrostu, Wydawnictwo Uniwersytetu Warszawskiego, Wydział Geografii i Studiów Regionalnych, Warszawa.

5. GUS (2018), Miasta w liczbach 2016, Główny Urząd Statystyczny, Warszawa, https://bdl. stat.gov.pl/ (dostęp: 21.06.2020).

6. https://ec.europa.eu/environment/nature/ecosystems/index_en.htm (dostęp: 16.06.2020).

7. Iwan S. (2013), Wdrażanie dobrych praktyk w obszarze transportu dostawczego w miastach, Wydawnictwo Akademii Morskiej w Szczecnie, Szczecin.

8. Kijewska K. (2014), Działania na rzecz zrównoważonego miejskiego transportu towarowego w polskich miastach - ocena i perspektywy rozwoju, „Logistyka”, nr 3.

9. KGP (2020), Wypadki drogowe w Polsce w 2019 roku, Komenda Główna Policji, Warszawa http://statystyka.policja.pl/ (dostęp: 28.06.2020).

10. Klepacki B., Koper M. (2017), Stan i kierunki rozwoju infrastruktury drogowej w Polsce, „Ekonomika i Organizacja Logistyki”, nr 2(4).

11. Korneć R. (2018), System transportu miejskiego wobec zrównoważonego rozwoju, „Studia Miejskie", t. 30.

12. Krysiuk C., Nowacki G. (2016), Miasto, element systemu transportowego kraju, „Autobusy Technika, Eksploatacja, Systemy Transportowe”, nr 10.

13. Malecki K., Iwan S., Kijewska K. (2014), Influence of Intelligent Transportation Systems on Reduction of the Environmental Negative Impact of Urban Freight Transport Based on Szczecin Example, „Procedia - Social and Behavioral Sciences”, Vol. 151.

14. Mirabella N., Allacker K. (2018), The Assessment of Urban Environmental Impacts through the City Environmental Footprint: Methodological Framework and First Approach to the Built Environment, „Procedia CIRP”, Vol. 69, https://www.sciencedirect.com/science/ article/pii/S2212827117308399 (dostęp: 12.06.2020).

15. Nowakowska-Grunt J., Chłąd M. (2015), Mobilność jako element zarządzania miastem, „Zeszyty Naukowe Politechniki Częstochowskiej. Zarządzanie”, nr 20.

16. Realizatorzy celów (2018), Załącznik 5 do Strategii \#Warszawa2030, http://2030.um warszawa.pl/ (dostęp: 12.06.2020). 
17. Rzeńca A. (red.) (2016), EkoMiasto\#Środowisko. Zrównoważony inteligentny i partycypacyjny rozwój miast, Wydawnictwo Uniwersytetu Łódzkiego, Łódź.

18. Sosik K., Iwan S. (2018), Znaczenie sygnalizacji świetlnej do poprawy bezpieczeństwa transportu drogowego, „Autobusy - Technika, Eksploatacja, Systemy Transportowe”, nr 6.

19. Stawasz D. (2016), Wspótczesne dylematy zarządzania rozwojem miast, Wydawnictwo Uniwersytetu Łódzkiego, Łódź.

20. Strategia Rozwoju Krakowa (2018), Strategia Rozwoju Krakowa. Tu chcę żyć. Kraków 2030, Załącznik do Uchwały nr XCIV/2449/18 Rady Miasta Krakowa z dnia 7 lutego 2018 r., https://www.bip.krakow.pl/ (dostęp: 11.06.2020).

21. Strategia Rozwoju Łódzkiego Obszaru Metropolitalnego 2020+ (2019), Łódzki Obszar Metropolitalny, Łódź, http://archiwum.uml.lodz.pl/miasto/strategia/ (dostęp: 08.06.2020).

22. Strategia \#Warszawa2030 (2018), Strategia rozwoju m.st. Warszawy do 2030 roku przyjęta przez Radę m.st. Warszawy 10 maja 2018 r., Urząd m.st. Warszawy, Warszawa, http://2030. um.warszawa.pl/ (dostęp: 12.06.2020).

23. Szołtysek J. (2005), Logistyczne aspekty zarządzania przeptywami osób i ładunków w miastach, Wydawnictwo Uniwersytetu Ekonomicznego w Katowicach, Katowice.

24. Szymańska D. (2007), Urbanizacja na świecie, Wydawnictwo Naukowe PWN, Warszawa.

25. Wiktorska-Święcka A. (2016), Zarzadzanie miastem. Wyzwania dla Europejskiej Stolicy Kultury Wrocław 2016, Oficyna Wydawnicza Atut, Wrocławskie Wydawnictwo Oświatowe, Wrocław.

\title{
MODERN URBAN TRANSPORT SYSTEMS IN CONTEXT OF SUSTAINABLE DEVELOPMENT IN POLAND
}

\begin{abstract}
Ensuring the effective and efficient movement of loads and people in urban transport systems affects the quality of life and increases competitiveness against other cities. The concept of the sustainable development of cities is a response to their dynamic growth, the changing needs of their inhabitants and to the need to limit the negative effects of urban transport systems. The aim of the article is to identify the activities planned by the Administrators of selected Polish cities in the context of the development of sustainable transport systems. The adopted research methodology is limited to a systematic review of the Development Strategy in terms of developed objectives and intended activities. An analysis of Polish and English literature was used to verify individual aspects of the article.
\end{abstract}

Keywords: urban transport system, city development strategy, sustainable development, sustainable transport system 